\title{
A MORE ACCURATE HALF-DISCRETE HILBERT-TYPE INEQUALITY WITH A GENERAL NON-HOMOGENEOUS KERNEL AND OPERATOR EXPRESSIONS
}

\author{
Qiliang Huang, Aizhen Wang And Bicheng YAng
}

\begin{abstract}
In this paper, by the use of the methods of weight functions and technique of real analysis, a more accurate half-discrete Hilbert-type inequality with a general non-homogeneous kernel and a best possible constant factor is given. The equivalent forms and some reverses are obtained. We also consider the operator expressions with the norm and some particular examples.
\end{abstract}

Mathematics subject classification (2010): 26D15, 47A07.

Keywords and phrases: Half-discrete Hilbert-type inequality, weight function, equivalent form, reverse, Hilbert-type operator.

\section{REFERENCES}

[1] G. H. Hardy, J. E. Littlewood, G. Pólya, Inequalities, Cambridge University Press, Cambridge, 1934.

[2] D. S. Mitrinović, J. E. PeČARIĆ, A. M. FinK, Inequalities involving functions and their integrals and derivatives, Kluwer Acaremic Publishers, Boston, 1991.

[3] B. C. YANG, Hilbert-type integral inequalities, Bentham Science Publishers Ltd., Sharjah, 2009.

[4] B. C. YANG, Discrete Hilbert-type inequalities, Bentham Science Publishers Ltd., Sharjah, 2011.

[5] B. C. YAng, The norm of operator and Hilbert-type inequalities, Science Press, Beijin, China, 2009.

[6] B. C. YANG, Hilbert-type integral operators: norms and inequalities, Nonlinear nalysis, stability, approximation, and inequalities (eds. P. M. Paralos et al.), Springer, New York, (2012), 771-859.

[7] B. C. YANG, On Hilbert's integral inequality, Journal of Mathematical Analysis and Applications, 220, (1998), 778-785.

[8] B. C. Yang, I. Brnetić, M. Krnić, J. E. PeČarić, Generalization of Hilbert and Hardy-Hilbert integral inequalities, Math. Ineq. and Appl., 8, 2 (2005), 259-272.

[9] M. KRniĆ, J. E. PeČARIĆ, Hilbert's inequalities and their reverses, Publ. Math. Debrecen, 67 3-4, (2005), 315-331.

[10] B. C. YANG, TH. M. RASSIAS, On the way of weight coefficient and research for Hilbert-type inequalities, Math. Ineq. Appl., 6, 4 (2003), 625-658.

[11] B. C. YANG, TH. M. RASSIAS, On a Hilbert-type integral inequality in the subinterval and its operator expression, Banach J. Math. Anal., 4, 2 (2010), 100-110.

[12] L. AZAR, On some extensions of Hardy-Hilbert's inequality and Applications, Journal of Inequalities and Applications, 2009, no. 546829.

[13] B. ARPad, O. Choonghong, Best constant for certain multilinear integral operator, Journal of Inequalities and Applications, 2006, no. 28582.

[14] J. C. Kuang, L. Debnath, On Hilbert's type inequalities on the weighted Orlicz spaces, pacific J. Appl. Math., 1, 1 (2007), 95-103.

[15] W. Y. Zhong, The Hilbert-type integral inequality with a homogeneous kernel of Lambda-degree, Journal of Inequalities and Applications, 2008, no. 917392.

[16] Y. Hong, On Hardy-Hilbert integral inequalities with some parameters, J. Ineq. in Pure \& Applied Math., 6, 4 (2005), Art. 92, 1-10. 
[17] W. Y. Zhong, B. C. YANG, On multiple Hardy-Hilbert's integral inequality with kernel, Journal of Inequalities and Applications, Vol. 2007, Art.ID 27962, 17 pages, doi: 10.1155/ 2007/27.

[18] B. C. YANG, M. KRnić, On the norm of a mult-dimensional Hilbert-type operator, Sarajevo Journal of Mathematics, 7, 20 (2011), 223-243.

[19] Y. J. LI, B. HE, On inequalities of Hilbert's type. Bulletin of the Australian Mathematical Society, 76, 1 (2007), 1-13.

[20] B. C. YANG, A mixed Hilbert-type inequality with a best constant factor, International Journal of Pure and Applied Mathematcs, 20, 3 (2005), 319-328.

[21] B. C. YANG, A half-discrete Hilbert-type inequality, Journal of Guangdong University of Education, 31, 3 (2011), 1-7.

[22] W. Y. ZHONG, A mixed Hilbert-type inequality and its equivalent forms, Journal of Guangdong University of Education, 31, 5 (2011), 18-22.

[23] W. Y. ZHONG, A half discrete Hilbert-type inequality and its equivalent forms, Journal of Guangdong University of Education, 32, 5 (2012), 8-12.

[24] J. H. ZHONG, B. C. YANG, On an extension of a more accurate Hilbert-type inequality, Journal of Zhejiang University (Science Edition), 35, 2 (2008), 121-124.

[25] J. H. ZHONG, Two classes of half-discrete reverse Hilbert-type inequalities with a non-homogeneous kernel, Journal of Guangdong University of Education, 32, 5 (2012), 11-20.

[26] W. Y. ZhONG, B. C. YANG, A best extension of Hilbert inequality involving several parameters, Journal of Jinan University (Natural Science), 28, 1 (2007), 20-23.

[27] W. Y. ZHONG, B. C. YANG, A reverse Hilbert's type integral inequality with some parameters and the equivalent forms, Pure and Applied Mathematics, 24, 2 (2008), 401-407.

[28] M. Y. Zhong, B. C. YANG, On multiple Hardy-Hilbert's integral inequality with kernel, Journal of Inequalities and Applications, Vol. 2007, Art.ID 27962, 17 pages, doi: 10.1155/ 2007/27.

[29] B. C. YANG, Q. CHEN, A half-discrete Hilbert-type inequality with a homogeneous kernel and an extension, Journal of Inequalities and Applications, 124 (2011), doi:10.1186/1029-242X-2011-124.

[30] B. C. YANG, A half-discrete Hilbert-type inequality with a non-homogeneous kernel and two variables, Mediterranean Journal of Methematics, 2012, doi: 10.1007/s00009- 012- 0213-50 online first.

[31] B. C. YANG, Two types of multiple half-discrete Hilbert-type inequalities, Lambert Academic Publishing, Berlin, 2012.

[32] J. C. Kuang, Applied inequalities, Shangdong Science Technic Press, Jinan, China, 2004.

[33] J. C. KuANG, Introduction to real analysis, Hunan Education Press, Chansha, China, 1996.

[34] Y. L. Pan, H. T. Wang, F. T. Wang, On complex functions, Science Press, Beijing, China, 2006. 